\title{
Defining Online Hate Speech under Indonesia Legal System: Implication For Sustainable of Justice
}

\author{
V Prahassacitta \\ Faculty of Humanities, Universitas Bina Nusantara, Jakarta, Indonesia \\ vidya.prahassacitta@binus.ac.id
}

\begin{abstract}
Online hate speech relates to sustainable development, therefore this research has two objectives. First, to define legal concepts of hate speech under Indonesia legal system. Second, to recognize whether the legal concept of hate speech supports Indonesia's sustainable development goals. Then, as normative legal research, secondary data collected through a literature study from legal data sources, including legislation and twenty court decisions from year 2004 until early 2018. Using analytical and historical approaches, the data is categorized and analysed to meet with the research objectives. The result concludes that because of anti-hate speech provisions determinate to promote peace and stability, thus the definitions of hate speech beyond to promote hatred against the particular group based on their identity or characteristics. This obstructs not only freedom of speech, but also the sustainable development goals.
\end{abstract}

Keywords: Speech, Indonesia, Sustainable

\section{INTRODUCTION}

In September 2015, United Nation has adopted the 2030 agenda for sustainable development goals and since that Indonesia has embraced the sustainable development goals. Parts of the goals are to end poverty and hunger in all forms as well as to ensure dignity and equality for every people. Accordingly, to John Rawls's theory, right is prior to the good means that individual basic rights including political liberty and freedom of speech shall be exercised first prior social and economic advantages [1]. Then to actualizing the goals, equality shall be opened to all, which in John Rawls perfective requires some changes or tools to improve certain group's to achieve that social and economic prospects [2].

An obstruction to reach that goal is hate speech, an issue that becomes enormous issues in this Internet and social media eras. Hate speech is a familiar concept but it is complicated to describe. It is an ordinary concept that uses by people within a range of other social, cultural, political and economic domains. It generally explains as a harmful speech that attacks people on the based of their race, ethnicity, nationality, religion, sexual orientation, disability, and gender identity. The kind of speech is forbidden because such speech implicates issues of harm, dignity, security, and democracy. On the other hand, legal scholars have a specific concept of it based on the characteristic of hate speech that relates to a particular body of law and legal regime [3]. Subsequently, the definitions of hate speech bias between both ordinary and legal concepts.

The concept of hate speech remains question under Indonesia legal system. Indonesia penal policy declares that promoting hates speech is categorized as a crime. There are three 
legislations regulate the prohibition of hate speech, Penal Code, Information and Electronic Transaction Act, and Anti Discrimination Act. Unfortunately, formulation of anti-hate speech in those legislations is unclear. Development of the legal concept also provides by twenty court verdicts from year 2004 until early 2018. Under the civil law system, court verdict parts of legal source beside legislation.

Therefore, this research attempts to define the legal scope of hate speech under Indonesia legal system and to recognize whether the definition supports sustainable development goals. Next, to answering the question, it requires to recognize purposes of hate speech prohibition under Indonesia legal system. It is towards to next problem whether the developments of the concept in line with the original purpose of the prohibition of hate speech and sustainable development goals. Analyzing is limited only to define the legal concepts of hate speech. The object of this research is both online and offline hate speech with a central focus in online hate speech.

\section{METHOD}

The research is a normative legal research, which is using secondary data collected through a literature study. Legislations and court verdicts analyzed as the primary legal source in conjunction with secondary and terrier legal source. Analytical and historical approaches use to analyze anti-hate speech in every legal regime in Indonesia. Research stared by collecting data then data was grouping based on the research problem. Analyzing data was conducted to answer research questions then to deliver conclusions.

\section{RESULTS and DISCUSSION}

\subsection{Legal Concept of Hate Speech in Legislations}

Hate speech prohibition has regulated, but Indonesia does not have a formal juridical definition of hate speech. Creating a hate speech definition is tricky, but by analyzing anti-hate speech legislations, it can provide the scope of the legal concept of hate speech.

Table 1. Anti-Hate Speech Provisions Under Indonesia Legal System.

\begin{tabular}{|c|c|c|c|}
\hline & Penal Code & $\begin{array}{c}\text { Information and } \\
\text { Electronic Transaction } \\
\text { Act }\end{array}$ & Anti Discrimination Act \\
\hline Article & $156,156 \mathrm{a}$ and 157 & $\begin{array}{l}28 \text { paragraph (2) and } \\
\text { 45A paragraph (2) }\end{array}$ & $\begin{array}{l}\text { Article } 4 \text { point } \mathrm{b} \text { and } \\
\text { Article } 16\end{array}$ \\
\hline Offenses & $\begin{array}{l}\text { Expressed statements } \\
\text { or conduct of } \\
\text { hostility, hatred or } \\
\text { humiliation in writing } \\
\text { or orally; } \\
\text { Expressed statements } \\
\text { that or conduct an } \\
\text { activity that avoid } \\
\text { people become an } \\
\text { atheist }\end{array}$ & 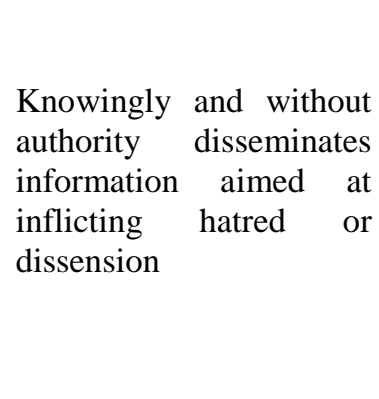 & $\begin{array}{l}\text { Intentionally show hatred } \\
\text { or hatred toward people } \\
\text { because of racial and } \\
\text { ethnic differences In } \\
\text { writing or orally in a } \\
\text { public space; }\end{array}$ \\
\hline
\end{tabular}




\begin{tabular}{llll} 
Victim & Certain group & $\begin{array}{l}\text { Individual, a certain } \\
\text { group }\end{array}$ & $\begin{array}{l}\text { Individual, a certain } \\
\text { group }\end{array}$ \\
Scope & $\begin{array}{l}\text { Races, ethnic groups } \\
\text { and religious }\end{array}$ & $\begin{array}{l}\text { Ethnic groups, religions, } \\
\text { races, and intergroup }\end{array}$ & $\begin{array}{l}\text { Races, ethnic group } \\
\text { Implication }\end{array}$ \\
$\begin{array}{l}\text { Creating hostility in } \\
\text { society }\end{array}$ & Creating hostility & Creating hostility \\
\hline
\end{tabular}

Hate speech prohibition first introduces in Indonesia through the Penal Code, Dutch colonial legacy legislation, which has applied since 1918. Hate speech parts of hatzaiartikelen, a Dutch terminology, which translate as articles that containing criminal penalties for a person expressing humiliation, hatred, hostility to the government, certain groups, either in writing or orally. Inhibitions for promoting racial and ethnic hatred regulate in article 156 and 157 Penal Code. Then in 1965, Indonesia Government toward article 4 Law No. 1 the Year 1965 has imposed new article in Penal Code, known as article 156 a. An additional provision bans a promoting religious hatred. Purposes of that exclusion are to maintain peace and public order among the Indonesia society.

Article 156 a Penal Code dissimilar with blasphemy, which describes as irreverence toward God, religion, a religious icon, or something else considered sacred [4]. Indonesia does not have blasphemy provision. Historically, blasphemy act introduces in Germany in 1930s and its inspired the Dutch Government to issued similar act. However, it does not adopt in Indonesia Penal Code. Article 156 a Penal Code introduces not to protect religions but to avoid statements that deliver hostile feelings, hatred or demeaning to a particular population or religion and to avoid people become an atheist [5]. Politically the article issued by President Sukarno to accommodate requests from Islamic organizations to prohibit mystical indigenous beliefs. At that time, politically, mystical indigenous beliefs close to the organizations affiliated to the Communist Party [6]. Practically, prevent religious hostility the primary concern of this article, and it reinforced in Constitutional Court Verdict No. 140/PUU$\mathrm{VII} / 2009$.

The specific purpose of anti-hate speech provision in Information and Electronic Transaction Act remains an issue. Anti-hate speech formulation in Penal Code and Information and Electronic Transaction Act are almost the same, except formulation in the last legislation considers more persuasive. The article does not exclusively apply for online hate speech violation; in fact, the Penal Code also applies. Thus the general purpose of anti-hate speech provision in both legislations shall be the same.

Anti Discrimination Act has a different purpose with two previous legislations. Indonesia had ratified the Convention on The Elimination of All Forms of Racial Discrimination (CERD) and as a consequence, the legislation issued. CERD bans propaganda based on ideas or theories of superiority of one race or group of persons of one color or ethnic origin, or attempt to justify or promote racial hatred and discrimination in any form. The concept base on the dignity and equality principles under the Universal Declaration of Human Rights (UDHR). Dignity formulates not to be understood as personal honor or self-esteem but as the sense of entitlement to regard in society as an equal and in good standing. Therefore a hate speech regulation does not an aim to redress individual or partial accounts of harm but actual harms, which affect every member of society [7]. The Legislation separate hate crime with hate speech. Hate crime can describe as a crime against persons or property motivated in whole or in part by racial, ethnic, religious, gender, sexual orientation and other prejudices [8]. Commonly hate speech precedes hate crime. The provision regulates in article $4 \mathrm{~b}$ point 4 and article 17 . 
The problem, hate speech formulations in those three legislations prohibit the same actions. It considers as overlapping because it is re-criminalization of the same crime in several legislations [9]. Subsequently, it creates an ambiguous among law enforcers regarding differences between those legislations and which provides that shall use.

Aside from the legislation, the legal concept of hate speech can also be analyzed from the Head Indonesia National Police Letter No. SE/6/X/2015. Handling hate speech cases in society is the purpose of the letter. Scopes of hates speech expanded. The content of hate speech expands including promoting hatred to an individual or certain group based on sexual orientation, disability, and gender identity. On the other side, the expanded generate confusion. In the letter defamation, which regulates in article 310 and 311 Penal Code and article 27 paragraph (3) and 45A paragraph (1) Information and Electronic Transaction Act, categorize as part of hate speech. Although group defamation often uses to describe hate speech, defamation provides punishment for those who intentionally and negligent insult an individual [10].This includes libel and slander [11]. This contradictory to a hate speech, which threatens, insult or degrades a group of people based on race, ethnicity, nationality, religion, sexual orientation, disability, and gender identity. Thus, the letter generates bias.

\subsection{Legal Concept of Hate Speech in Court Verdict}

The definition of hate speech develops more extensive than initial, but it deviates. As describe in table

2 , hate speech not only describes as an action that promoting hatred against the certain group based on their identity or characteristics but also categorize as blasphemy, sedition, and defamation. In the most cases, hate speech defines as blasphemy which it does not regulate under Indonesia legal system. Sedition and hate speech are different concepts, even though both crimes have to violate public peace. Sedition describes as conduct or speech inciting people to rebel against the authority of a state, and the speech shall not require hatred against specific groups based on their identity or characteristics.

Then both group defamation and individual defamation are classified in hate speech concept. Group defamation does accept in the concept, but individual defamation does not. In Rizal Kobar, Jamar and AlfianTanjung cases defamations are addressed to politic figures that associated with certain groups.

Table 2.The Scopes of Hate Speech According to Court Verdicts.

\begin{tabular}{|c|c|c|c|c|c|c|c|c|}
\hline \multirow{3}{*}{ Case } & \multirow{3}{*}{ Legislation } & \multirow{3}{*}{ Year } & \multicolumn{2}{|c|}{ Media } & \multicolumn{4}{|c|}{ Court Verdict } \\
\hline & & & \multirow{2}{*}{$\begin{array}{l}\text { On } \\
\text { line }\end{array}$} & \multirow{2}{*}{$\begin{array}{l}\text { Off } \\
\text { line }\end{array}$} & \multirow{2}{*}{$\begin{array}{l}\text { Blas } \\
\text { phemy }\end{array}$} & \multirow{2}{*}{$\begin{array}{c}\text { Promoting } \\
\text { Hatred }\end{array}$} & \multirow[t]{2}{*}{ Sedition } & Defamation \\
\hline & & & & & & & & $\begin{array}{ll}\text { Indivi } & \text { Group } \\
\text { dual } & \\
\end{array}$ \\
\hline $\begin{array}{l}\text { Mangapin } \\
\text { Sibuea }\end{array}$ & 156 a Penal Code & 2004 & & $\mathrm{X}$ & X & $\mathrm{X}$ & & \\
\hline Ardi Husain & 156 a Penal Code & 2005 & & $\mathrm{X}$ & & & & \\
\hline Yusman Roy & 157 Penal Code & 2005 & & $\mathrm{X}$ & & $\mathrm{X}$ & & \\
\hline $\begin{array}{l}\text { Ahmad } \\
\text { Tantowi }\end{array}$ & 156 a Penal Code & 2010 & & $\mathrm{X}$ & $\mathrm{X}$ & & & \\
\hline $\begin{array}{l}\text { Oben Sarbeni } \\
\text { bin H Hodin }\end{array}$ & 156 a Penal Code & 2011 & & $\mathrm{X}$ & $\mathrm{X}$ & & & \\
\hline Alexander AN & 28 (2) Information & 2012 & $\mathrm{X}$ & & $\mathrm{X}$ & & & \\
\hline
\end{tabular}




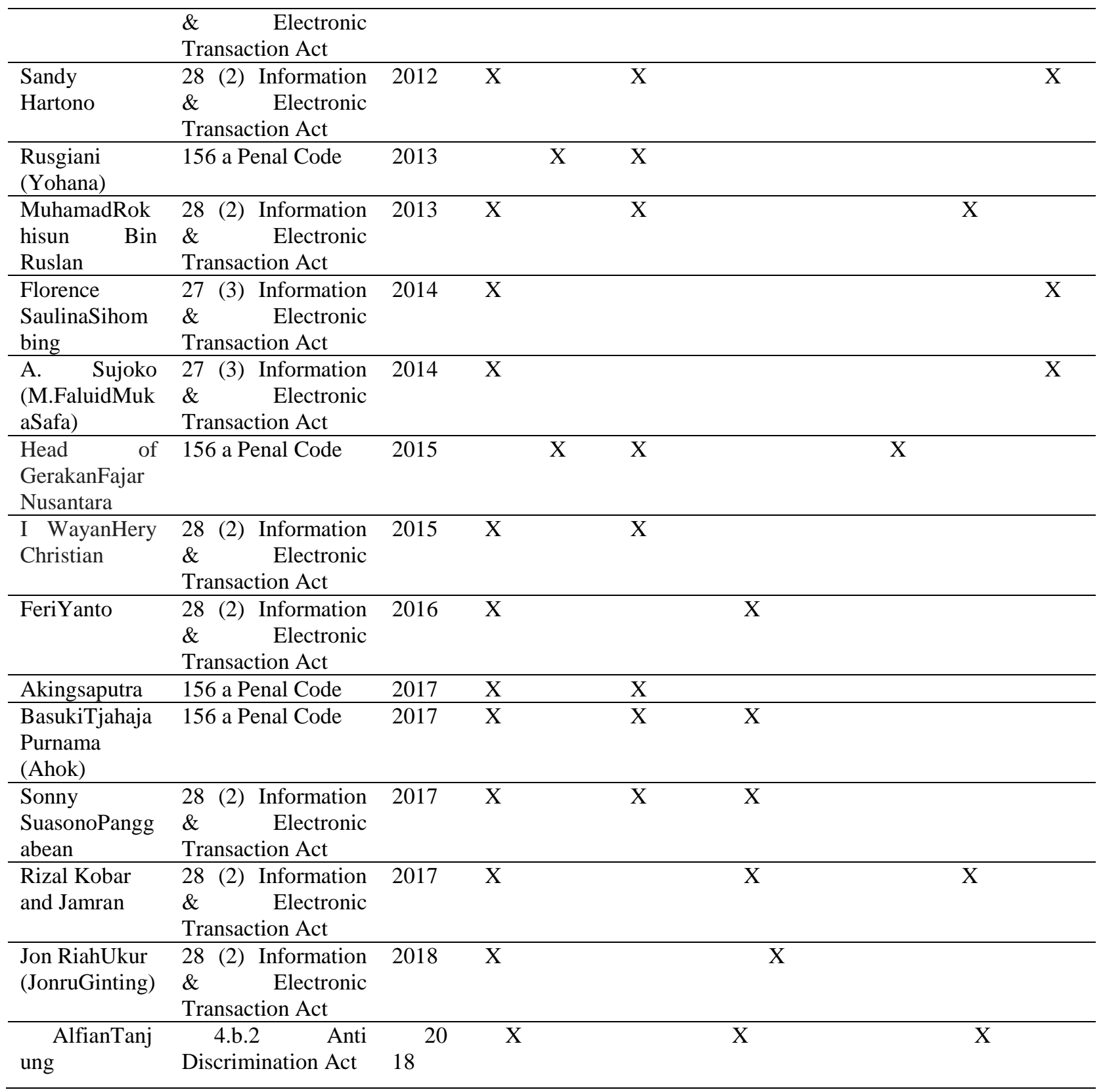

Anti-hate speech provision applies to prevent a riot. Although it interpreted deviate from the original definition, the anti hates speech provisions commonly used because its purposes to promote peace. In Feri Yanto case, hate speech prohibition in Information and Electronic Transaction Act applies, even though his speech does not mention any to race, ethnicity, nationality, religion, sexual orientation, disability, and gender identity issues. 


\subsection{Legal Concept of Hate Speech to Support Sustainable Development Goal}

There is no consensus on the definition of sustainable development concept, yet the concept could be described as balance and continuity. Quote from Rio de Janeiro Earth Summit 1992 document, it describes "sustainable development is one that meets the needs of the present without compromising the ability of future generations to meet their own needs." It seeks a balance between human needs, economic growth, and the environment. Maintaining resources for future generations and social justice issues are also part of the concept [12].

Sustainable development goals related to the human right. In 2015, United Nation General Assembly consent 17 sustainable development goals. Although the human right issue does not highlight in sustainable development goals, human right is key essential to achieve sustainable development goals. An international human right convention such as CERD has been influential factors on sustainable development idea. Inequality and discrimination, which mentions in the goals, are at the center of struggles of human right [13]. The goals, for example no poverty and zero hunger, could be filled if there are discrimination and inequality for the minority group. Both are a barrier for minority or certain groups to exercise their right and freedom. When minority or certain group slost their freedom of speech it means that they will lose their economic and social rights and benefits. Therefore minority or certain groups shall be protected with legislations.

Hate speech threatened sustainable development goals. It is a violation of freedom of speech, which generates discrimination and inequality. Not only asserts a personal opinion, it but also prevent certain groups from participating in deliberative decision making [14], including policy decision related to sustainable development goals. Ideally, hate speech shall prohibit to support sustainable development goals

In fact, anti-hate speech provisions do not fully support sustainable development goals that Indonesia adopted. As mention before, Indonesian anti-hate speech provisions have purposes not only to maintain human dignity and equality, but also to maintain peace and public order among the Indonesia society, which the second purpose considers the primary purpose. Indeed that purposes support sustainable development goals. However, the applications are contrary. Because of unclear formulation of the legal concept of hates speech, Judges define the legal concept of hate speech very broadly including certain crimes that originally shall not classify as hate speech. Consequently, it generates misuse of the provisions. Anti-hate speech provisions in article 156 a Indonesia Penal Code and article 28 article (2) Information and Electronic Transaction Act often apply to silence freedom of speech. In several cases, it follows with mass mobilization such as in Basuki Tjahaja Purnama (Ahok) and I Wayan Hery Christian cases. In both cases, the defendants are non-Muslims and mass are organized by Muslim organizations. Although it difficult to detect discrimination and inequality against certain groups from the above court verdicts, both cases indicate that majority group uses both articles as a tool to silence individual or minority group's right and freedom, including freedom of speech. Subsequently it makes social and law enforcement conditions worst. Moreover, Basuki Tjahaja Purnama (Ahok) case generates negative impact in political right and freedom especially right to be voted and participating in deliberative decision-making. In the end, a proper anti-hate speech provision requires for Indonesia, which has diversity in culture, religion, ethic, and language, to support the implementation of sustainable development goals. 


\section{CONCLUSION}

Anti-hate speech provision under Indonesia legal system has a primary purpose to promote peace and stability. It applies in cases that disturbing public order even though in some cases the speech does not mention hatred against the certain group based on their characteristic or identity. Therefore, the legal concept of hate speech defines beyond than promoting hatred against the specific group based on race, ethnicity, nationality, religion, sexual orientation, disability, and gender identity, but also including blasphemy, sedition, and defamation. In fact, those are different crimes and shall not classify as hate speech. Consequently, application of anti-hate speech provision does not in line with initial purpose and scope of the provisions. In the end it not only violates freedom of speech but also generates a negative effect, which might obstruct the implementation of sustainable development goals.

\section{REFERENCES}

[1] M. J. Sandel and J. Rawls, "Political Liberalism," Harv. Law Rev., vol. 107, no. 7, p. 1765, May 1994.

[2] J. Rawls, A Theory of Justice. Cambridge: Harvard University Press, 1999.

[3] A. Brown, "What is hate speech? Part 1: The Myth of Hate," Law Philos., vol. 36, no. 4, pp. 419-468, Aug. 2017.

[4] H. C. Black, Black's Law Dictionary. St. Paul: West Publishing, 2009.

[5] O. Senoadji, Hukum (Acara)Pidana Dalam Prospeksi. Jakarta: Erlangga, 1981.

[6] M. A. Crouch, "Law and Religion in Indonesia: The Constitutional Court and the Blasphemy Law," Asian J. Comp. Law, vol. 7, pp. 1-46, Apr. 2012.

[7] J. Waldron, The Harm in Hate Speech. Cambridge: Mass. Harvard, 2012.

[8] J. B. Jacobs and J. S. Henry, "The Social Construction of a Hate Crime Epidemic," J. Crim. Law Criminol., vol. 86, no. 2, p. 366, 1996.

[9] D. Husak, Over Criminalization. New York: Oxford University Press, 2008.

[10] J. Waldron, "Dignity and Defamation: The Visibility of Hate," Harv. Law Rev., vol. 123, no. 7, pp. 1597-1657, 2010.

[11] V. Prahassacitta, "Citizen Journalism in Cyber Media: Protection and Legal Responsibility Under Indonesian Press Law," Humaniora, vol. 8, no. 1, p. 45, Jan. 2017.

[12] G. S. Barbosa, P. R. Drach, and O. D. Corbella, “A Conceptual Review of the Terms Sustainable Development and Sustainability," Int. J. Soc. Sci., vol. 3, no. 2, pp. 1-15, 2014.

[13] K. Arts, "Inclusive sustainable development: a human rights perspective," Curr. Opin. Environ. Sustain., vol. 24, pp. 58-62, Feb. 2017.

[14] A. Tessis, "Dignity and Speech? Regulation of Hate Speech in a Democracy," Wake Forest Law Rev., vol. 44, pp. 497-532, 2009. 